\begin{tabular}{|c|c|c|}
\hline Jurnal Peneletian Kesmasy & Vol. 3 No. 1 & Edition: November 2020 - April 2021 \\
\hline & http://ejournal.delihusada.ac.id/index.php/JPKSY & \\
\hline Received: 16 September 2020 & Revised: 03 Oktober 2020 & Accepted: 27 Oktober 2020 \\
\hline
\end{tabular}

\title{
Hubungan Tingkat Pengetahuan dan Perilaku Perawat terhadap Risiko Kegiatan Pembuangan Limbah Medis Padat Di Ruang Syifa Dan UGD RS Haji Jakarta Tahun 2015
}

\author{
Desi Aryani \\ Program Studi Teknologi Laboratorium Medis, Universitas Binawan \\ Korespondensi : aryanidesi93@yahoo.com
}

\begin{abstract}
Hospital is one of the health care facilities that have complex characteristics especially concerning the interaction between the various processes, scientific devices and various types of health workers who are related to each other. In addition to a positive impact, the Hospital had negative impacts that generate waste during its activities; one of waste is solid medical waste. Solid medical waste is one of the sources of pollution, so it is necessary to conduct an integrated management starting from segregation to the disposal of solid medical waste. Researcher raised this issue because there were incident afflicting health workers and cleaning services at Haji Hospital Jakarta, they were punctured used needles. In a period of 2 years from 2014 to 2015, there had been 5 cases of used needles should not happen.This research usequantitative and qualitative methods. Quantitative research conducted by distributing a questionnaire to measure the level of knowledge (age, length of work, education, training), facilities and behavior of nurses and cleaning services to the risk of solid medical waste disposal activities. The qualitative research conducted with indepth interviews. Result of the relation between nurse knowledge against the risk of solid medical waste disposal based on the result of the $t$-test $1.661<t$-table 2000. Result of the relation between nurse behavior with the risk of medical waste disposal activities based on the result of the t-test $1.975<t$-table 2000. Result of the relation between of the level nurse knowledge and nurse behavior with the risk of solid medical waste disposal based on the result $f$-count $3.036<f$-table 3.35. So there is no relation between nurse knowledge and nurse behavior with the risk of medical waste disposal activities at Haji Hospital Jakarta.
\end{abstract}

Keywords: knowledge, behavior, nurses, the risk of medical solid waste disposal 


\section{PENDAHULUAN}

Pelayanan kesehatan yang paripurna sangatlah diharapkan masyarakat hal ini sejalan dengan tujuan pemerintah untuk mewujudkan upaya peningkatan derajat kesehatan sesuai amanah Undang-undang Dasar 1945. Rumah sakit merupakan salah satu fasilitas kesehatan yang mempunyai karakteristik kompeks tertama menyangkut interaksi antara berbagai proses, perangkat keilmuan dan beragam jenis tenaga kesehatan yang saling berkaitan satu sama lain. Dalam mendukung operasionalnya, rumah sakit harus dilengkapi dengan bangunan, sumber daya manusia, serta sarana dan prasarana agar terjami kesehatan, keamanan dan keselamatan kerja bagi pasien, petugas, pengunjung dan lingkungan rumah sakit tersebut.

Berdasarkan profilkesehatan Indonesia Tahun 2013 yang dikeluarkan oleh kementerian kesehatan sejak tahun 2011 sampaidengan tahun 2013 terjadi peningkatan jumlah rumah sakit. Pada tahun 2011 ada 1.721 rumah sakit di Indonesia, pada tahun 2013 jumlah ini meningkat 29,5\% menjadi 2.228 rumah sakit (Kementerian Kesehatan RI, 2014)

Rumah sakit dapat membawa dampak positif dan negatif yaitu menghasilkan limbah selama kegiatan, salah satunya limbah infeksius atau limbah padat. Menurut peraturan No 101 pada tahun 2014 Limbah Bahan Berbahaya dan Beracun yaitu sisa-sisasuatukegiatanyang mengandungsuatu zat,energi dan atau komonen lain karena sifat, konsentrasi dan atau jumlahnya, secara langsung atau tidak langsung mencemarkan, merusak, membahayakan lingkungan hidup, kesehatan serta kelangsungan hidup manusia dan mahluk hidup lainnya. Limbah infeksius adalah limbah medis padat yang terkontaminasi organisme patogen dalam jumlahdan virulensi yang cukup untuk menularkan penyakit pada manusia rentan : limbah dari perawatan pasien, limbah berupa benda tajam, limbah patologi, pembiakan infeksius \&limbah sitoktoksik (PP 101 tahun 2014)

Pada tahun 2009 di enam rumah sakit dikota Bandung, Makassar dan Medan oleh Direktorat Jenderal Penyehatan Lingkungan yang didukung World Health Organization, hasil kajian tersebut menunjukan persentase $65 \%$ rumah sakit sudah melakukan pemilihan antara limbah medis dan limbah domestik seperti kantong plastik kuning dan hitam. Akan tetapi masih sering terjadi salah tempat, pada persentase $65 \%$ rumahsakitmempunyaiincinerator dengan suhu pembakaran antara 530-800 ${ }^{\circ}$ (Ditjen PP \& PL, 2011).

Berdasarkan dari perkiraan Depatermen Kesehatan Republik Indonesia pada tahun 2003, timbunan limbah medis dalam satu tahun sebesar 8.132 ton dari 1.686 seluruh rumah sakit di Indonesia. Pada tahun 2003 timbunan limbah medis dari rumah sakit sekitar 0,14 Kg/TT (tempat tidur). Komposisi pada limbah 
medis terdiri dari limbah non infeksius $80 \%$, limbah patologi dan infeksius $15 \%$, limbah benda tajam $1 \%$, limbah kimia \& farmasi $3 \%$ dan tabung \& thermometer pecah $>1 \%$ (Ditjen PP \& PL, 2011).

\section{METODE}

Jenis data penelitian didapatkan dari data internal yang berasal dari rumah sakit dan data eksternal yang berasal dari luar rumah sakit dengan teknik pengumpulan data secara cross sectional. Sampel pada penelitian ini berjumlah 61 subjek di Rumah Sakit Haji Jakarta. Penelitian ini Penelitian ini dilakukan bulan Juli Desember 2015.

Pengumpulan data diawali dengan data internal yang berasal dari rumah sakit dan data eksternal yang berasal dari luar rumah sakit. Kemudian dilakukan dengan pengisian kuisioner, wawancara dan Observasi pengumpulan data melalui proses pencatatan sistematik tanpa adanya pertanyaan atau komunikasi dengan individu - individu yang diteliti. Analisa data dilakukan secara univariat dan bivariat (Uji statistik koefisien korelasi Pearson Product Moment) menggunakan software statistik.

\section{HASIL DAN PEMBAHASAN}

Hasil observasi di Unit Syifa dan UGD terdapat limbah medis padat dari limbah patologi, limbah farmasi, limbah benda tajam, limbah infeksius, limbah kontainer bertekanan, limbah kimiawi dan limbah dengan kandungan logam berat yang tinggi.
Jumlah limbah medis padat dari tiap-tiap ruangan dilakukan pencatatan setiap hari oleh petugas kebersihan dengan diketahui oleh petugas ruangan dan petugas sanitasi:

Tabel 1. Produksi Limbah

Medis Periode Januari-September 2015

\begin{tabular}{llcc}
\hline No & Bulan & BOR & $\begin{array}{c}\text { Jumlah } \\
\text { Limbah } \\
\text { Medis(Kg) }\end{array}$ \\
\hline $\mathbf{1}$ & Januari & 62 & $2.882,37$ \\
\hline $\mathbf{2}$ & Februari & 70,2 & $2.893,62$ \\
\hline $\mathbf{3}$ & Maret & 68 & $3.384,7$ \\
\hline 4 & April & 64 & $3.361,7$ \\
\hline 5 & Mei & 60,7 & $3.368,42$ \\
\hline 6 & Juni & 79 & $3.394,44$ \\
\hline 7 & Juli & 59,02 & 4.369 \\
\hline 8 & Agustus & 64,28 & 4.136 \\
\hline 9 & September & 65,75 & 3.779 \\
\hline
\end{tabular}

Hasil uji validitas dan uji reliabilitas, nilai cronbach's alpha diperoleh sebesar 0,763 artinya kuesioner yang dibuat sudah reliabel karena $\geq 0,60$. Hasil hubungan tingkat pengetahuan terhadap risiko pembuangan limbah medis paat di ruang Syifa dan UGD diperoleh koefisien Pearson Product Moment sebesar 0,209 berdasarkan dari pedoman interpretasi koefisien korelasi menurut Sugiyono (2013) dalam Susila dan Suyanto (2014: 170) maka keeratan hubungan tingkat pengetahuan perawat terhadap risiko kegiatan pembuangan limbah medis padat 
adalah rendah dengan konstribusi sebesar 4,3\%.Signifikansi koefisien korelasi Pearson Product Moment didapat t-hitung $1,661<$ t-tabel maka tidak ada hubungan tingkat pengetahuan perawat terhadap risiko kegiatan pembuangan limbah medis padat, artinya hubungan tingkat pengetahuan terhadap risiko kegiatan pembuangan limbah medis padat rendah, hal ini dapat di dukung oleh penelitian sebelumnya Jasmawati dengan judul "Hubungan Pengetahuan, Sikap, dan Ketersediaan Fasilitas dengan Praktik Petugas Pengumpul Limbah Medis di RSUD Abdul Wahab Sjahranie Samarinda" yang dalam penelitian ini menunjukan bahwa hasil Chi Square diperoleh nilia $\mathrm{P}=0,146>\mathrm{a}(0,05)$ hal ini tidak ada hubungan antara pengetahuan dengan pratik petugas pengumpul limbah medis disebabkan sebagian besar petugas pengumpul limbah memiliki pengetahuan baik $75,6 \%$ dan melakukan pengumpulan secara baik $86,7 \%$.

Hubungan perilaku perawat terhadap risiko pembuangan limbah medis padat diruang Syifa dan UGD besarnya koefisien Korelasi Pearson Product Moment sebesar 0,247 maka keeratan hubungan perilaku perawat terhadap risiko kegiatan pembuangan limbah medis padat adalah rendah konstribusi sebesar $6,1 \%$. Signifikansi koesfisien korelasi Pearson Product Moment di dapat t-hitung 1,976 < t-tabel maka tidak ada hubungan perilaku perawat terhadap risiko kegiatan pembuangan limbah medis padat. Artinya tingkat hubungan perilaku dan risiko kegiatan pembuangan limbah medis padat rendah. Hal ini dapat di dukung oleh peneliti sebelumnya Naela Fadhila dengan judul "Hubungan Pengetahuan, Sikap, dan Perilaku Tentang Faktor Risiko Penyakit Serebrovaskular Terhadap Kejadian Stroke Iskemik" Responden yang mengalami stroke dengan perilaku baik sebanyak 19 dengan presentase 63,3\% sedangkan dengan perilaku buruk sebanyak 11 dengan presentase $36,7 \%$, nilai $P$ value 0,126 , interval kepercayaan $95 \%(0,724-7,407)$ dengan rasio odd 2,316. Artinya hubungan signifikan antara perilaku tentang faktor risiko penyakit serebrovaskular terhadap kejadian stroke iskemik mungkin terjadi karena perilaku didahului oleh pengetahuan dan sikap sehingga sikap dan pengetahuan yang baik memungkinkan responden untuk memiliki perilaku yang baik pula.

Hubungan tingkat pengetahuan dan perilaku perawat terhadap risiko kegiatan pembuangan limbah medis padat besarnya koefisien korelasi Pearson Product Moment sebesar 0,307 ini apa bila di hubungkan dengan pedoman interpretasi koefisien korelasi maka keeratan hubungan antara pengetahan dan perilaku perawat terhadap kegiatan pembuangan limbah medis padat rendah. Signifikasi koefisien korelasi ganda di dapatkan hasil F-hitung dibandingkan dengan F-tabel dengan taraf kepercayaan 5\% dan derajat kebebasaan $(\mathrm{dk})=\mathrm{n}-\mathrm{k}-1$. Dengan F-hitung 3,036 < F-tabel 3,35, maka koefisien korelasi ganda tersebut tidak signifikan. Artinya tidak ada hubungan tingkat 
pengetahuan dan perilaku dengan risiko kegiatan limbah dengan koefisien korelasi ganda tersebutadalah tidak signifikan hal ini didukung dengan penelitian sebelumnya olehMohamad Ridwan Nasirudin dengan judul "Tingkat Pengetahuan dan Sikap dengan Perilaku Pencegahan Penularan Tuberculosis (TB) di Wilayah Keja Puskesmas Ngempal Kabupaten Boyolali" Berdasrkan hasil penelitian ini diketahui responden yang berpengetahuan baik dan berperilaku baik sebanyak 11 orang dengan persentase $61,1 \%$ dan responden yang berpengetahuan buruk dan berprilaku buruk didapat hasil sebanyak 5 orang dengan persentase $55,6 \%$. Hasil uji statistik didapat nilai Fisher's Exact Test $\mathrm{P}=$ $0,448>0,05$ bahwa tidak ada hubungan antara tingkat pengetahuan dengan perilaku pencegahan penularan TB di wilayah kerja Puskesmas Ngemplak Kabupaten Boyolali.

\section{KESIMPULAN}

Berdasarkan pembahasan yang telah di dapat bahwa dari hasil penelitian tentang hubungan tingkat pengetahuan dan perilaku perawat terhadap risiko kegiatan pembuangan limbah medis padat di ruang Syifadan UGD Rumah Sakit Haji Jakarta tahun 2015 dapat disimpulkan bahwa tidak ada hubungan pengetahuan perawat terhadap risiko kegiatan pembuangan limbah medis padat di RS. Haji Jakarta, tidak ada hubungan perilaku perawat terhadap risiko kegiatan pembuagan limbah medis padat di
RS. Haji Jakarta.

\section{DAFTAR PUSTAKA}

Departemen Kesehatan RI. 2002. Pedoman Sanitasi Rumah Sakit di Indonesia. Jakarta: Direktorat Jendral PPM \& PPL dan Direktorat Jendral Pelayanan Medik

Ditjen PP \& PL. 2011. Kebijakan Kesehatan Lingkungan Dalam Pengelolaan Limbah Medis di Fasyankes. Jakarta: Direktorat $\mathrm{PL}$

Kementerian Kesehatan RI. 2014. Sekretaroat Jndral Profil Kesehatan Indonesia Tahun 2013. Jakarta: Kementerian Kesehatan RI. ISBN 978-602235-645-5

Kementerian Kesehatan RI. 2014. Sekretariat Jenderal Profil Kesehatan Indonesia Tahun 2013.Jakarta: Kementerian Kesehatan RI. ISBN 978-602235-645-5.

Keputusan Menteri Kesehatan

Republik Indonesia. 2004. Nomor1204/MENKES/SK

/X/2004 tentang Persyaratan Kesehatan Lingkungan Rumah Sakit. Jakarta.

PeraturanMenteriKesehatan RI. 1992. Nomor 986/Menkes/ PER/XI/1992 tentang

Persyaratan Kesehatan Lingkungan Rumah Sakit. Jakarta.

Peraturan Menteri Kesehatan RI. 2010. Nomor 340/MenKes/Per /III/2010 tentang Klasifikasi Rumah Sakit. Jakarta.

Peraturan Pemerintah RI. 2014. 
Nomor 101 Tahun 2014

Tentang Pengelolaan Limbah

Bahan Berbahaya dan

Beracun. Jakarta.

Peraturan Pemerintahan RI. 2014.

Nomor 101 Tahun 2014

Tentang Pengelolaan Limbah

Bahan Berbahaya dan

Beracun. Jakarta

Sugiyono. 1999. Statistik Untuk Penelitian. Bandung: Penerbit CV Alfabeta 